\title{
Susan Sontag. Escritura, cinefilia y el cine como dispositivo de pensamiento crítico
}

\section{Susan Sontag. Writing, Cinephilia and the Cinema as a Device for Critical Thinking}

\author{
Luis Heriberto Valenzuela Prado \\ Universidad Andrés Bello \\ luis.valenzuela.p@unab.cl
}

\section{Resumen}

El trabajo ensayístico de Susan Sontag se basa en la tensión y discusión crítica entre estética, cultura, moral y política. En ese sentido, se vale de diversos objetos, disciplinas y teorías desde los cuales erige su pensamiento. Uno de estos es el cine, que opera como cinefilia, en tanto "specific kind of love that cinema inspired", y como dispositivo político que da cuenta de la decadencia del cine, pero a la vez de su espesor cultural e histórico. En esa línea, este artículo realiza una revisión bibliográfica del trabajo ensayístico de Susan Sontag en torno al cine y la cinefilia. Desde ahí, se busca articular una reflexión en torno al cine como dispositivo de escritura y pensamiento crítico y teórico.

Palabras clave: cinefilia, cine, Susan Sontag.

\section{Abstract}

Susan Sontag's essay work is based on the tension and critical discussion between Aesthetics, Culture, Morals and Politics. It is from this regard that she makes use of various objects, disciplines and theories from which her thinking is built. Cinema is one of these elements, working in the form of cinephilia as a "specific kind of love that cinema inspired", and as a political device giving an account of the decadence of cinema, but also of its cultural and historical density. In this respect, this article does a bibliographical review of Susan Sontag's essay work about cinema and cinephilia. From then on, this article seeks to articulate a reflection about cinema as a writing and critical and theoretical device.

Keywords: cinephilia, cinema, Susan Sontag. 


\title{
El proyecto de Sontag: Escribir para cambiar
}

\author{
El texto que usted escribe debe probarme \\ que me desea. Esa prueba existe: es la escritura. \\ La escritura es esto: la ciencia de los goces del \\ lenguaje, su kamasutra (de esta ciencia no hay \\ más que un tratado: la escritura misma)
} Barthes 14

"Yo escribo en parte para cambiarme a mí misma y así, una vez que he escrito sobre algo, no tener que volver a pensar en ello. Cuando escribo, escribo para sacarme ideas de encima" (Cott 125). Susan Sontag responde así a Jonathan Cott en su entrevista para Rolling Stone, dando cuenta de su forma de escritura y de pensamiento. En ese sentido, el trabajo ensayístico de Sontag se basa en la tensión y discusión crítica entre estética, cultura, moral y política. Una de las entradas para configurar ese mecanismo de "sacarse temas" es la imagen, tanto fotográfica como cinematográfica, esta última como manifiesta cinefilia y dispositivo crítico. Desde ese lugar vendría a erigir su propia contradicción, modelando una reflexión en torno al cine, el cual opera como o desde la cinefilia, en tanto "tipo específico de amor que el cine inspira" ("Un siglo de cine"), y como dispositivo político, cuya convergencia vincula un oscilante devenir entre el esplendor y la decadencia del cine, y asimismo de su espesor cultural e histórico.

En el prólogo a La conciencia uncida a la carne: Diarios de madurez 1964-1980 de Sontag, su hijo - y editor de estos- David Rieff declara que frente a su "infelicidad en el amor", en Sontag se erige el "sentimiento de realización profunda que derivaba de su escritura", acorde con su vida de "estudiante perpetua", una "suerte de lectora ideal de la gran literatura", de "crítica ideal del gran arte", de "espectadora ideal del gran teatro, el cine y la música" (La conciencia). Sontag, sin dudas, es una lectora y espectadora voraz y radical que prueba y desarrolla un pensamiento dinámico y propio. En 1996, al escribir el ensayo "Treinta años después..., observa en retrospectiva los ensayos de Contra la interpretación, y es tajante al afirmar que no se trata de un "ejercicio saludable", ya que su energía escritora, que se saca temas de encima, la "impulsa a mirar hacia delante, a sentir que aún estoy empezando", tensionando su impaciencia frente a esa "escritora incipiente" ("Treinta"). Una lectora y escritura que se proyecta hacia nuevas lecturas y no tanto hacia una escena nostálgica de saberes, condición intrínseca de una ensayista, por el contrario, siempre está empezando, ahora, sin perder de vista la articulación de un pensamiento estético y político.

Como lectora de Barthes entiende la tendencia del teórico francés a las taxonomías, aunque, por defecto, enfatiza que estas "nunca son estáticas", por cierto, generalmente, su objetivo es que una "categoría subvierta a otra" con la intención de "mantener abiertos los temas, para reservar un lugar a lo no codificado, lo encantado, 
lo intratable, lo histórico" ("La escritura"). La escritura como ciencia del goce, como se lee en el epígrafe de este artículo, se decanta en Sontag en su manera de abrir temas, de subvertir categorías, en sus palabras desde una "erótica del arte" y desde la transparencia: "Transparence is the highest, most liberating value in art —and in criticism - today. Transparence means experiencing the luminousness of the thing in itself, of thing being what they are" (Against interpretation 13). ${ }^{1}$ Ahora, según ella, apelar a una "erótica del arte" no significa "menospreciar el papel del intelecto crítico" (“Treinta”), por lo tanto, este artículo rastrea y traza algunas ideas en torno al cine, desde su cinefilia desbordada, que le permite dar una pasada por una amplia lista de directores y películas, funda además el valor de su forma de ver/leer crítica y erótica, y comprenderlo desde el placer y el amor por este, y cómo la cinefilia, como experiencia, es puesta en jaque desde la industria del cine.

Si consideramos la idea del escribir para cambiar — que también permite desviarse en la problemática del ensayo-, el cine, en esa operación, adquiere una doble función al ser aprehendido desde la cinefilia que es tan ociosa o inútil en tanto experiencia placentera de ver y apreciar, como crítica y política al devenir en dispositivo teórico que encadena un pensamiento urdido en un amplio tejido o corpus cinematográfico. El gesto, entonces, en Sontag, oscila entre el placer y la crítica.

\section{Escritura, cine y el fin de la cinefilia}

El cine - en un tiempo proclamado el arte del siglo $\mathrm{xx}$ - parece ahora, cuando el siglo toca a su fin, un arte en plena decadencia. Pero tal vez lo que ha terminado no sea el cine, sino solo la cine-

filia, ese tipo específico de amor que inspiraba Sontag, "Un siglo".

Los teóricos van al cine es un buen título que tomo de la colección que dirige el crítico argentino de cine Gonzalo Aguilar, cuyos dos primeros títulos son Borges va al cine y Roberto Arlt va al cine. Libros que dan cuenta de una experiencia y de un contexto cultural que rodea a los escritores que ven en el cine una posibilidad de ampliar, en rigor, modificar, los fundamentos de la letra. Ahora, cuando digo los teóricos van al cine imagino una escena de Susan Sontag asistiendo a una sala de cine, experimentando una forma de pensamiento crítico desde ese dispositivo. El impacto

1 Traducción del autor: "Hoy la transparencia es el más alto y más liberador valor en el arte -y en la crítica-. La transparencia significa experimentar la luminosidad del objeto en sí, de las cosas tal como son". 
del cine repercutió en artes como el teatro, la fotografía y la literatura, también en quienes quisieron pensarlo desde la teoría. Los textos de directores como Eisenstein sobre el montaje en el cine o de Jean Epstein, como La inteligencia de una máquina. Una filosofía del cine (1946). Por su parte, Walter Benjamin — quien dedicó varias páginas a la reflexión en torno a la imagen- escribe, en 1927, el texto "La situación del arte cinematográfico en Rusia", aunque luego, entre 1934 y 1936, publica "La obra de arte en la era de la reproductibilidad técnica", donde asume que la obra de arte surge en el cine "solo a partir del montaje" (45), pero también de la relación entre el intérprete de cine y el "sistema de aparatos" (51) desemboca, en última instancia, en la relación con la masa, espectadora, que será la que supervise desde la invisibilidad. A fines de los años cincuenta e inicios de los sesenta resulta fundamental el trabajo de André Bazin. Más tarde, en los años ochenta, Gilles Deleuze realiza sus entregas sobre la imagen-movimiento y la imagen-tiempo en el cine. Es cierto, el cine tiene su propia teoría, pero la filosofía, por ejemplo, también tiene su vínculo especial con el cine. Otros teóricos, no necesariamente teóricos del cine, desarrollan ciertas reflexiones en torno al cine, menores, como Michel Foucault, por ejemplo, que si bien no realizó un trabajo sistemático, sí esbozó algunas ideas recogidas en el libro Foucault va al cine, el cual agrupa diez textos, muchos de ellos entrevistas, en los que el teórico francés analiza ciertos aspectos del cine. ${ }^{2}$ Por su parte, Slavoj Žižek —en Lacrimae Rerum. Ensayos sobre el cine moderno y ciberespacio- presenta, según Valeria de los Ríos, "uno de los acercamientos recientes más provocativos en torno al cine". Žižek, en clave sicoanalista y lacaniana, siempre lúcido en sus lecturas, elabora los ejes y funcionamientos de cumbres del cine como Hitchcock, Kieslowski, Tarkovski y Lynch, y como bonus track Matrix de los hermanos Wachowski. Pienso, sobre todo, en Jacques Rancière, quien, en El destino de las imágenes, abre con una reflexión en torno a El azar Baltazar de Jean Luc Bresson, para dar cuenta de "operaciones que enlazan y desvinculan lo visible y su significación o la palabra y su efecto, que producen y desvían las expectativas" (El destino 26). Un acercamiento más profundo, en tanto objeto cinematográfico, lo expone en Fábula cinematográfica y en Las distancias del cine.

Me detengo unas líneas en Rancière ya que este, al igual que Sontag, fundamenta las bases de su pensamiento sobre el cine en la cinefilia. Ambos vivieron la cinefilia con edades similares, en décadas del esplendor cinematográfico, Rancière nace el año 1940 y Sontag el año 1933. De algún modo en ambos opera una cinefilia desde la experiencia y la crítica, entendiendo que esa dualidad actúa desde zonas distintas. En ambos la cinefilia de la formación, la pasión y la vivencia da paso a una cinefilia crítica y teóri-

2 Patrice Maniglier y Dork Zabunyan, autores y compiladores del libro, sugieren que esa distancia con el cine se explicaría porque "la época que lo engendró no es suficientemente lejana y porque el archivista no posee la distancia necesaria para describir los efectos y mutaciones del mundo de las imágenes" (30), lo que se explicaría, cotejando lo expuesto por Foucault en La arqueología del saber, asumiendo que el análisis del archivo requiere una "región privilegiada", cercana, pero "diferente de nuestra actualidad" (172, en Maniglier y Zabunyan 30). 
ca, incluso política. Cuando Rancière abre Las distancias del cine apunta una serie de recuerdos en torno a sus primeros acercamientos, digamos cinéfilo, al cine. Primero, un premio que recibe en Italia por su libro La fábula cinematográfica, país en el que había terminado el liceo. Tal "conjunción" (Las distancias 9), señala, revelaba algo de su vínculo con el cine. Sin duda, ese país, Italia, había influido en su formación: el cine de Rossellini, las revistas y libros que un amigo cinéfilo italianizante le enviaba desde Roma, en los que buscaba "aprender al mismo tiempo la teoría del cine, el marxismo y la lengua italiana" y la "curiosa trastienda de una taberna napolitana" donde recuerda haber visto una película de Nicholas Ray (9). Rancière no evoca esos recuerdos por una mera y nostálgica "ternura sentimental por esos años remotos", sino "porque dibujan bastante bien la singularidad de mi abordaje del cine" (10), en rigor, su acercamiento al cine no es como filósofo ni como crítico, en sí su relación la entiende como "un juego de encuentros y distancias [...]" (10). Estas últimas, las distancias, articuladas en tres tipos, desde las cuales busca hablar de cine: cine y arte, cine y política, y cine y teoría (10). Pensando en la primera distancia, y la sala improvisada para ver la película de Ray, Rancière configura la idea de cinefilia, la cual define como:

relación con el cine que es asunto de pasión antes de ser cuestión de teoría. Se sabe que la pasión carece de discernimiento. La cinefilia era una confusión de los discernimientos admitidos. Una confusión de los lugares, ante todo: una singular diagonal trazada entre las cinematecas donde se conservaba la memoria de un arte y las salas de barrio alejadas donde se proyectaba tal o cual filme hollywoodense despreciado y donde los cinéfilos, no obstante, reconocían su tesoro en la intensidad de la cabalgata de un western, el asalto a un banco o la sonrisa de un niño. La cinefilia ligaba el culto del arte a la democracia de las diversiones y las emociones, recusando los criterios a través de los cuales el cine se hacía admitir en la cultura distinguida (10).

A la vez, Rancière valora el cine en tanto multiplicidad, sea el lugar material donde uno va a divertirse o ese otro cine que recompone nuestros recuerdos y palabras (13), una utopía, "un concepto filosófico, una teoría del movimiento mismo de las cosas y el pensamiento, como en Gilles Deleuze" (14). Esa multiplicidad permite complejizar la idea de cinefilia desde el concepto de amateur. Rancière señala que nunca enseñó el cine, "ni su teoría, ni su estética" (15), se topó con este en diversos momentos de entusiasmo o cuestionamiento (15). En esa dirección, el amateurismo es una "posición teórica y política, la posición que recusa la autoridad de los especialistas al reexaminar la manera como se trazan las fronteras de sus dominios en el cruce de las experiencias y los saberes" (15). En rigor, la "política del amateur" asevera que el cine pertenece a quienes "han viajado al interior del sistema de distancias" y tránsitos desde y hacia el cine, "y que cada cual puede autorizarse a trazar, entre tal o cual punto de esas tipografías, un itinerario singular que agrega al cine como mundo y a su conocimiento" (15). 
Sontag coincide implícitamente con Rancière al elaborar su trabajo desde la tríada que implica pasión, formación y amateurismo, la cual deriva en lo que ella entiende por cinefilia. En 1995, para el centenario del cine, Sontag apunta que, a diferencia de otras artes, el "amor infundido por el séptimo arte [...] era especial", los cinéfilos, los amantes del cine creían que "solo existía este, que las cintas lo encerraban todo [...]" ("Un siglo"). Del celo intelectual y artístico que provoca en un inicio cine, se pasa a la cinefilia intelectual y posterior pérdida de esta misma. Una forma simple es la que enuncia Antoine de Baecque (2006), definiéndola como una forma de ver las películas, hablar sobre ellas y difundir ese discurso. Ximena Vergara esboza la idea de critica de cine actual, de medios de prensa e Internet como un "ejercicio de escritura que se encarga de descomponer filmes para observarlos formal, estética y críticamente" (40-41), asumiendo la cinefilia como un "concepto adecuado para pensarla como género" (41). Para De Valck y Hagener esta apunta, por un lado, a la experiencia fílmica que evoca particulares "sensations of intense pleasure resulting in a strongly felt connection with the cinema, often described as a relation of love"3 (11), siendo los cinéfilos cautivados por la "magic of moving images" (11). Por otro lado, el término da cuenta de prácticas y discursos en los cuales el término es apropiado por "agendas dogmáticas", como la "politique des auteurs". ${ }^{4}$ Al ver filmes de Hollywood, Truffaut, Godard, Rohmer descubren apasionadas preferencias por ciertos cineastas populares de Hollywood, a los que legitiman en sus escritos en Cahiers du Cinéma. Este discurso acredita la construcción de un arquetipo de cinéfilo omnisciente que "became central to the (elitist) mode of film reception known as cinephilia” (De Valck y Hagener 11). Por su parte, para Ana Sedeño Valdellós la cinefilia se entiende, por un lado, como una "reacción al contexto cultural de la posguerra centroeuropea (en concreto francesa)" y, por otro, "como un fenómeno propio del cambio de paradigma de la estética del arte que ha sido denominado por Jauss posmodernidad estética" ("Nueva cinefilia"). En esa orientación, los lineamientos de la Escuela de Frankfurt y conceptos como el de ideología de Althusser se configuran desde el nacimiento del "movimiento cinematográfico más importante para la idea básica de la naturaleza de la cinefilia: la Nouvelle Vague francesa”, la cual es seguida de otros nuevos cines como el Cinema Novo brasileño, el Free Cinema inglés. Tanto autores como intelectuales de la Nouvelle Vague muestran un fuerte compromiso político, que "supuso un revulsivo para la cultura del cine, tanto que puede atribuírsele su invención" (Sedeño Valdellós).

Volviendo a Sontag, y a la tríada que sustenta su cinefilia, se puede establecer que esta se muestra en su producción escritural, ya que escribió más sobre cine que sobre

3 Traducción del autor: "Sensaciones de intenso placer que desembocan en un fuerte sentimiento y conexión con el cine, a menudo, descritos como una relación de amor".

4 De Valck y Hagener citan a Colin MacCabe, quien señala que la "politique des auteurs" "was not only concerned with establishing the primacy of the film- maker-director, but also aimed at the creation of a new "perfect" audience" (11). 
literatura, no por un gusto mayor por el primero que por la segunda, sino porque le "gustaban más las nuevas películas que las nuevas novelas" (“Treinta”). De ahí que uno de sus logros mientras terminaba Contra la interpretación "es que no pasaba día sin que viera, por lo menos una, a veces dos o tres, películas”, momento en el que el cine, sin duda alguna, "era el arte ejemplar". La apertura de Sontag hacia el cine, como sostiene su biógrafo Daniel Schreiber, queda plasmada desde el acceso que pueden dar una pintura de Jasper Jons, la música de los Beatles hasta una película de Godard, ya que se "podían disfrutar sin condescendencias en tanto complejas y sensuales experiencias de la percepción” (125).

Cuando Sontag escribe su ensayo sobre los cien años del cine comenta que pareciera que esta conmemoración "hubiera adoptado las fases de un ciclo vital: el nacimiento inevitable, la acumulación progresiva de gloria, y el inicio, durante el último decenio, de una decadencia ignominiosa e irreversible" ("Un siglo"). Sin duda, manifiesta, seguirán apareciendo nuevas películas, heroicas, "vigentes por doquier en la producción cinematográfica del mundo capitalista", que convivirán con otras cuya simple finalidad es el entretenimiento, en rigor, se trata de películas comerciales, las cuales "seguirán siendo pasmosamente necias". El cine propone, con su aura de arte del siglo xx, adopta en su centenario la forma de "un arte en decadencia" o el fin de la cinefilia. El fin de ciclo coincide con el fallecimiento de Sontag a inicios del siglo xxI, por lo que se erige como testigo de la gloria y ocaso del cine como fenómeno, como experiencia, como forma de ver.

Todas las artes, escribió Sontag, “engendran sus fanáticos”. El melómano, el coleccionista de arte, el bibliófilo o lector compulsivo. El Quijote, Borges, Bolaño o Benjamin en su bello texto "Desempacando mi biblioteca". Sin embargo, asume que "el amor infundido" por el cine "era más señorial", surge de la convicción de que es diferente a todas las artes: "la quintaesencia de lo moderno; patentemente accesible y, al mismo tiempo, poético, misterioso, erótico y moral. Tuvo sus apóstoles (era como una religión). El cine era una cruzada. Una forma de ver el mundo" ("Un siglo"). Los fanáticos de otras artes no creían que la suya fuese la única, los amantes del cine sí, que este era "el compendio del arte y el libro de la vida al mismo tiempo" ("Un siglo"). El cine como experiencia y forma única de ver el mundo.

El deseo y admiración en torno al cine Sontag lo sitúa en los inicios de este. En esa dirección, La llegada de un tren da cuenta de la "maravilla de que la realidad podía transcribirse con tan mágica inmediatez" ("Un siglo"). Todo comienza cuando el tren hace su ingreso en la estación: "La gente asimiló las películas, al igual que el público gritaba lleno de excitación, y en verdad se encogía, cuando la locomotora parecía dirigirse hacia ellos" ("Un siglo"). El cine fue, para sus espectadores, un lugar de aprendizaje: caminar, fumar, besar, sufrir: "Pero fuera lo que se aprendiese en ellos era solo una parte de la vivencia más amplia que consiste en perderse en los rostros, en las vidas que no son la propia: es la manifestación del deseo más inclusiva encarnada en la experiencia del cine. La más intensa era sencillamente entregarse, dejarse llevar, 
por lo que ocurría en la pantalla" (“Un siglo”). Esa entrega gratuita sienta las bases de la cinefilia, del amor, y, por cierto, de una erótica del arte.

Para Sontag, la búsqueda del cine se sustentaba en la búsqueda de la experiencia intensa, oscilante entre sensibilidad y crítica, una entrega "a lo que ocurría en la pantalla, introducirse en ella. Deseabas que la película te arrebatase" ("Un siglo"), ante la "abrumadora presencia física de la imagen", resultando imprescindible "ir al cine", por cierto, manifiesta que ver una gran película en televisión era "realmente como sino la hubieras visto" ("Un siglo"). El arrebato, postula, se experimenta en el anonimato, sentado en una sala cinematográfica oscura. Hoy, se queja Sontag, las imágenes pueden ser vistas en todo tipo de dispositivos, tamaños y superficies: cine, hogar, discotecas, estadios y edificios públicos: Tal ubicuidad de la imagen en movimiento ha hecho mella en los parámetros del público "en cuanto entretenimiento popular" ("Un siglo").

La posterior llegada del sonido provoca una pérdida aurática del cine y sus imágenes, ya que su "esplendor y poesía" se ajustan a criterios comerciales ("Un siglo"). Un dominio comercial que va desde 1930 a 1955, periodo en el cual directores como Von Stroheim y Welles se exilian en Europa ("Un siglo"). A mediados de los años cincuenta, en tanto, resurgen las ideas de vanguardia "arraigadas en el concepto de cine como oficio iniciado por las películas italianas de la posguerra" ("Un siglo"). Surge una "edad de oro" que dura aproximadamente veinte años, periodo en que "ir a ver películas, pensar en las películas y hablar de las películas se convirtió en una pasión entre los estudiantes universitarios y otros jóvenes. No solo te enamorabas de los actores, sino del propio cine". Ese modo de ver y experimentar el cine es la esencia de la cinefilia, enfatizando el amor, la pasión y el placer un deseo por el objeto cinematográfico acompañado, en Sontag, por un contexto político. Esa época es la que en Francia convoca Cahiers du Cinéma, con una "generación de jóvenes críticos" ("Un siglo"), siendo una de las figuras centrales Jean-Luc Godard, director fundamental para el amor por el cine y pensamiento de Sontag.

La década del sesenta y los inicios de los setenta marcan una "época de fiebre por el cine, llena de cinéfilos de dedicación exclusiva siempre a la espera de encontrar un asiento lo más cerca posible de la gran pantalla" ("Un siglo"). Sontag dice que la cinefilia abarca "tanto las películas artísticas como las populares" ("Un siglo") y su nacimiento coincide, a su vez, con "el ocaso de los estudios de Hollywood”. La cinefilia - una fuente de exultación en las películas de Godard y Truffaut y en la primera época de Bertolucci y Syberberg; un taciturno lamento en algunos de los recientes filmes de Nanni Moretti- se vio restringida en su mayor parte a la Europa occidental. Los grandes directores de "la otra Europa" (Zanussi en Polonia, Angelopolous en Grecia, Tarkovski y Sokurov en Rusia, Janciso y Tarr en Hungría) y los grandes directores japoneses (Ozu, Mizoguchi, Kurosawa, Oshima, Imamura) no han sido propensos a ella, tal vez porque en Budapest, Moscú, Tokio, Varsovia o Atenas no había oportunidad de adquirir una educación de filmoteca. El carácter distintivo del gusto del cinéfilo es que va dirigido tanto a los filmes artísticos como a los populares. En consecuencia, la 
cinefilia europea tuvo una relación romántica con las películas de ciertos directores de Hollywood de la época del apogeo de sus estudios: Godard con Howard Hawks, o Fassbinder con Douglas Sirk. Sontag percibe en el cine una especie de recuperación del "derecho a la experimentación", una suerte de renacimiento que al menos durante un periodo de 15 años entrega "nuevas obras maestras casi cada mes, y uno podía permitirse el lujo de pensar que eso iba a durar siempre", no obstante, nuevamente algo se pierde y la balanza se inclina al "lado del cine como industria" ("Un siglo").

Las cinefilias posteriores, surgidas a partir de los años ochenta, según Lluís Fecé, las de la televisión, el pop rock, el video y los computadores, "han construido otros marcos de referencia" (12), el cine y la industria han cambiado y las revistas se "refugian en una cinefilia trasnochada empeñada en ver el cine como lo que fue en lugar de lo que es" (13). En ese sentido, la nostálgica cinéfila - la enfermedad de la patria se deja leer desde Homero- empaña la lectura política del presente. Es la misma Sontag la que toma distancia de esa posibilidad, al declarar que una característica interesante de los "años sesenta" era la escasa nostalgia, por el contrario, se trata de un "momento utópico" (“Treinta”). El mundo en que escribí los ensayos de Contra la interpretación ya no existe, y el momento de su presente, 1996, "vivimos en una época que se vive como el fin - más precisamente, como justo después del fin- de todo ideal y de la cultura”.

En los ochenta, agrega Sontag, aumentan los costos de producción, lo que consolidó "los criterios industriales de realización y distribución de películas a una escala mucho más coercitiva” y global (“Un siglo"). En esa línea, propone un modelo de cinefilia política comprometida con una lectura desde el deseo del texto y una erótica. "Como era de prever", sostiene, "el amor por el cine ha menguado" ("Un siglo"), y si bien el público aún le gusta acudir a las salas, sintiendo un "verdadero interés y esperan algo especial, necesario en una película" ("Un siglo"), algo se perdió. Aunque surjan películas relevantes, asume que difícilmente se encuentra entre los jóvenes "ese característico amor cinéfilo", que no es solo amor por el cine, "sino un determinado gusto por las películas (basado en el gran apetito por ver una y otra vez, tanto como sea posible, el glorioso cine del pasado)" ("Un siglo"). Incluso la misma cinefilia resulta apuntada y atacada por ser considerada "algo extraño, pasado de moda, esnob" ("Un siglo"), ya que involucra una forma de experiencia con las películas, "únicas, irrepetibles, mágicas" ("Un siglo"). La cinefilia, entendida desde Sontag, es la crítica a la industria cinematográfica como brazo articulado del capitalismo, por lo cual no tiene un lugar en este contexto. En esa línea, nada tiene que ver la cinefilia con las superproducciones, porque defiende la idea de que una película es un "objeto poético; y no puede evitar incitar a aquellos que están fuera de la industria cinematográfica, como los pintores y los escritores, a que deseen también rodar películas" ("Un siglo"). Tanto la cinefilia como el cine han muerto, enfatiza Sontag, sin importar cuántas películas, "por muy buenas que sean, se sigan haciendo. Si el cine puede resucitar, será únicamente gracias al nacimiento de un nuevo género de amor por él" ("Un siglo"). 


\section{Teoría y dispositivo. De la caverna de Platón a la sala de cine}

Daniel Schreiber afirma que los críticos de cine norteamericano están de acuerdo en el aporte de los estudios de Sontag sobre cine: "Su pasión por esta disciplina [...] no solo quedó manifestada en numerosos análisis sobre la vanguardia cinematográfica europea y las películas del under norteamericano, sino que sus principios críticos desarrollados por ella a través del cine, también fueron aplicados a la literatura y el teatro" (Schreiber 158). La teoría garantiza un mecanismo preciso para configurar un dispositivo crítico articulado por imágenes e ideas. El cine, enfatiza Rancière, es un "aparato ideológico productor de imágenes que circulan en la sociedad y donde esta reconoce el presente de sus tipos, el pasado de su leyenda o los futuros que se imagina" (13). Aparato o dispositivo que posibilita la producción y lectura de esas imágenes reconociendo cruces temporales, temáticos, políticos y estéticos complejos. Como dispositivo puede ser resumido desde la lectura que hace Agamben a partir de ciertas reflexiones expuestas por Michel Foucault, ${ }^{5}$ como un discurso relacional, en tanto poder y saber. En su idea relacional, el dispositivo cinéfilo que articula Sontag, aporte teórico que enuncia Schreiber, se erige desde un constante cruce entre disciplinas: fotografía y cine, literatura y cine, sin dejar de lado el hilo de la lectura-deseo, política y crítica.

El cine, desde la cinefilia de Sontag, interviene su trabajo. Como recuerda al revisar su libro Contra la interpretación, el cine siempre estaba presente como pasión y pulsión. De este modo, Sontag no realiza un trabajo sistemático. Por cierto, se podría decir que se centra en desarrollar ciertos temas, escribo para cambiar, como esboza el origen de este artículo, los cuales son intervenidos por el cine. Dos son los ejes que podría articular estos aportes: primero, el cine como dispositivo que le permite llegar a ciertos problemas que busca discutir; segundo, homenajes precisos a directoras o directores. En el primer caso, una de las bases teóricas y filosóficas que utiliza Sontag para discutir el estatuto de la imagen es "La alegoría de la caverna" de Platón. El ensayo que abre Sobre la fotografía es "La caverna de Platón", en donde erige su teoría fotográfica: "La humanidad persiste irremediablemente en la caverna platónica" (13) y las imágenes proyectadas en esta buscan dar la impresión, simulada, de algo que no es real, pero sí alegórico, en cuanto al mundo y el conocimiento de este. En esa línea, la fotografía busca como resultado dar la "impresión de que podemos contener el mundo entero en la cabeza, como una antología de imágenes" (13). Así, la fotografía - expone Sontag - da cuenta de un conocimiento fijo, a diferencia de las imágenes cinematográfica y televisiva que "vacilan y se apagan" (13).

5 Agamben lo resume de esta manera: resume un primer acercamiento al concepto de en tres puntos, como: a) conjunto heterogéneo que incluye aspectos lingüísticos y no lingüísticos: discursos, instituciones, edificios, leyes, medidas de policía, proposiciones filosóficas. "En sí, el dispositivo es la red que se establece entre estos elementos" (8); b) "función estratégica concreta" siempre inscrita en una "relación de poder" (8); c) resultado del "cruce entre las relaciones de poder y relaciones de saber" (9). 
El punto relevante radica en que, en su intento por sacarse ideas de encima sobre el dispositivo de la imagen fija - la fotografía - en sus ensayos expone y desarrolla un aparataje cinematográfico referencial vasto y espeso, plasmando una reflexión tangencial sobre directores, como Dziga Vertov, Jean Luc Godard, Michelangelo Antonioni, Chris Marker y Alfred Hitchcock, los que podríamos ver en su real magnitud en la lista de 228 películas que Sontag redacta en 1977 y que su hijo, David Rieff, reduce a $50 .{ }^{6}$ Solo una nota del editor comenta que "SS abandona la lista en el número 228 " (La conciencia uncida a la carne). ¿Por qué la abandona? Los diarios no responden. ¿Por qué reduce la lista a 50? Rieff no responde. En parte, se puede pensar que Sontag no busca una lista total y final, menos articular un canon. En rigor, coquetea con las taxonomías barthesianas, entendiendo las mutaciones y no fijezas de estas, es decir, una lista intratable, desbordada, que nunca acabaría, reducida abruptamente por Rieff, decisión, incluso error, que él mismo declara al cerrar el prólogo.

Volviendo a su reflexión en torno al acontecimiento y el fotógrafo sostiene que el gesto de fotografiar "es esencialmente un acto de no intervención" ("La caverna" 21). Sontag ilustra la tensión entre intervenir o no con El hombre de la cámara (1929) de Dziga Vertov y La ventana indiscreta (1954) de Alfred Hitchcock, ambas películas que tensionan la imagen fija desde su mediación cinematográfica. La de Vertov brinda "la imagen ideal del fotógrafo como alguien en movimiento perpetuo, alguien que atraviesa un panorama de acontecimientos dispares con tal agilidad y celeridad que toda intervención es imposible" (22). Por su parte, la de Hitchcock muestra la "imagen complementaria" del fotógrafo estático, donde el fotógrafo, James Stewart, se relaciona con un suceso a través de la cámara, porque está en una silla de ruedas con una pierna rota. Sontag afirma que "la inmovilidad temporal le impide intervenir en lo que ve, y vuelve aún más importante hacer fotografías" (22). Sienta las bases de este ensayo en Platón, para dar un salto a la fotografía, sin embargo, no resiste volver al cine. A pesar de ser dispositivos diferentes, fijo y en movimiento, insiste en cruzar puentes, límites y territorios.

6 Mejores películas (en desorden) 1. Bresson, El ratero; 2. Kubrick, 2001; 3. Vidor, El gran desfile; 4. Visconti, Obsesión; 5. Kurosawa, El infierno del odio; 6. [Hans-Jürgen] Syberberg, Hitler ein Film aus Deutschland; 7. Godard, Dos o tres cosas que yo sé de ella; 8. Rossellini, La Prise de Pouvoir par Louis XIV; 9. Renoir, La regla de juego; 10. Ozu, Cuentos de Tokio; 11. Dreyer, Gertrud; 12. Eisenstein, El acorazado Potemkin; 13. Von Sternberg, El ángel azul; 14. Lang, El testamento del Dr. Mabuse; 15. Antonioni, El eclipse; 16. Bresson, Un condenado a muerte se ha escapado; 17. Gance, Napoleón; 18. Vertov, El hombre de la cámara; 19. [Louis] Feuillade, Judex; 20. Anger, Inauguración de la Cúpula del Placer; 21. Godard, Vivir su vida; 22. Bellocchio, Las manos en los bolsillos; 23. [Marcel] Carné, Los niños del paraíso; 24. Kurosawa, Los siete samuráis; 25. [Jacques] Tati, Playtime; 26. Truffaut, El pequeño salvaje; 27. [Jacques] Rivette, Amor loco; 28. Eisenstein, La huelga; 29. Von Stroheim, Avaricia. 30. Straub, La crónica de Anna Magdalena Bach; 31. Her[manos] Taviani, Padre Padrone; 32. Resnais, Muriel (El tiempo de un retorno); 33. [Jacques] Becker, La evasión; 34. Cocteau, La bella y la bestia; 35. Bergman, Persona; 36. [Rainer Werner] Fassbinder, Las amargas lágrimas de Petra von Kant; 37. Griffith, Intolerancia; 38. Godard, El desprecio; 39. [Chris] Marker, La Jetée; 40. Conner, Crossroads; 41. Fassbinder, La ruleta china; 42. Renoir, La gran ilusión; 43. [Max] Ophüls, Señora de...; 44. [Iosif] Kheifits, La dama del perrito; 45. Godard, Los carabineros; 46. Bresson, Lancelot del Lago; 47. Ford, Centauros del desierto; 48. Bertolucci, Antes de la revolución; 49. Pasolini, Teorema; 50. [Leontine] Sagan, Muchachas de uniforme. Se han mantenido los títulos originales de la traducción de los Diarios. 
Luego, al hablar del almacenamiento de imágenes, se refiere a Los carabineros (1963) de Godard, donde "dos perezosos lumpen campesinos" ingresan al ejército del rey con la promesa de que podrán "saquear, violar, matar o caer lo que se les antoje con el enemigo, y enriquecerse" ("La caverna" 13). La maleta que consiguen Michel-Angel y Ulyses - íconos del arte y la literatura respectivamente- para llevar a sus mujeres solo contiene postales de "monumentos, Tiendas, Mamíferos, Maravillas de la Naturaleza, Medios de Transporte, Obras de Arte y otros clasificados tesoros del mundo entero" (14). Sontag lee y entiende el gesto de Godard como una broma paródica al "encanto equívoco de la imagen fotográfica" (14), pero sobre todo lee y solidariza con la crítica a la sociedad del dinero.

En "Estados Unidos visto por fotografías, oscuramente", otro ensayo de Sobre la fotografía, reflexiona sobre las fotografías de Diane Arbus. Sontag cita a Luis Buñuel, cuando le preguntan "por qué hacía películas, respondió que era para 'mostrar que este no es el mejor de los mundos posibles"' (42), y así cotejarlo con el pensamiento de Arbus, quien tomaba fotografías "para mostrar algo más simple: que hay otro mundo" (42). La misma fotografía de Arbus empuja a Sontag a referirse a La parada de los monstruos - Freaks - (1932) de Tod Browning, la que muestra la escena del banquete de bodas, "cuando tarados, mujeres barbudas, siameses y torsos vivientes expresan bailando y cantando su aceptación de la maligna Cleopatra, de estatura normal, que acaba de casarse con el crédulo enano" ("Estados Unidos" 46). Sontag vincula esa escena de monstruos con el entusiasmo de Arbus al fotografiar monstruos, a los que termina adorando (46). Es que los años de la obra de Arbus concuerdan con la década de los sesenta "en que los monstruos se hicieron públicos y se transformaron en un tema artístico seguro y aprobado" (51). Si en los años treinta estas figuras cargaban con un sentido de angustia, en los sesenta se trata con impasibilidad o complacencia en el cine de Fellini, Arrabal, Jodorowsky (51).

Interesada en el cine y en las conexiones con otras disciplinas, en su ensayo "De la novela al cine: Berlin Alexanderplatz de Fassbinder" (1983), Sontag lo define como un "Arte híbrido y tardío", siempre en "diálogo con otros géneros narrativos", en un inicio con énfasis en el teatro ("De la novela"). No obstante, el teatro limitaba los elementos centrales del cine: "la intervención de la cámara, la movilidad de la perspectiva" ("De la novela”). Por ese motivo, la novela, que fluye de manera libre por el espacio y el tiempo, era más útil. No obstante, los resultados son disímiles, hay grandes novelas cuyo resultado es menor o novelas menores cuyo resultado es mejor. Godard, Resnais y Truffaut se inclinaron por géneros subliterarios: novelas de crímenes y aventuras, ciencia ficción: "Una novela menor podía servir como pretexto, como un repertorio de temas con los cuales el director puede jugar libremente" ("De la novela"), algo con lo que Hitchcock estaría muy de acuerdo. En ese juego de tránsitos desde la literatura hacia el cine, Sontag apuesta por el desborde de Berlin Alexanderplatz de Fassbinder, presentada en extenso en televisión -894 minutos-, logrando "parte de la estructura abierta y dilatoria y el poder acumulativo de la novela por atreverse a ser más larga 
que ninguna otra" ("De la novela"). Tal atrevimiento es el riesgo que la seduce, un arte que rompe sus límites y desafía los deseos del espectador.

La segunda forma señalada de abordar el cine es la de apuntar a directoras o directores específicos, por ejemplo, Leni Riefenstahl y, como ya se ha deja dejado entrever, Jean Luc Godard. En el prólogo a la entrevista en Rolling Stone Jonathan Cott coteja las dos visiones que contrapone Sontag en torno al cine de Leni Riefenstahl. Primero, en "Sobre el estilo" (1965) al llamarlas "obras maestras" (Cott 14) y luego en "Fascinante fascismo" asume que se trata de "la película de propaganda más pura jamás realizada" (Cott 14). Sontag ve y analiza acuciosamente la obra de la directora alemana, asume el riego de estar digiriendo un cine polémico. Esa recurrencia al cine de Riefenstahl permite volver a la idea de acabar los temas, un volver sobre ciertos ejes y rearticularlos. Resulta interesante, sobre todo, enfatizar el mecanismo de análisis que construye Sontag desde el cine mismo. Una suerte de "catálogo de la modernidad cinematográfica experimental, ante todo europea" (160), como sostiene Daniel Schreiber en Susan Sontag. Intelectualidad y glamour. Una biografía.

Ahora, es Godard el centro de atención de Sontag. La relectura de los ensayos de Estilos radicales, según versa el "Postfacio" que escribe para la edición española de 1985, la lleva a pensar que estos son "extremadamente personales", desde distintas formas autobiográficas, pero sobre todo se erigen como "una variedad de experiencias apasionadas que, como cuadra a una sensibilidad moderna, me llegó bajo la forma de sacudones" (291), en especial al "sacudón de Godard" (291). Lo que amaba en los años de la primera edición de Estilos radicales lo sigue amando en 1985, sin embargo, "los objetos de mi ardor eran tan frágiles de lo que imaginaba. Conquistas que parecían abrir las puertas de una nueva era, como las películas de Godard, llegaron a parecer más bien una culminación de lo antiguo" (292). Si bien el sacudón Godard valida la forma de experimentar la escritura y la lectura de Sontag, esta también asume que el fuego inicial, de algún modo, se apagaba.

En los años sesenta, su gran revelación había sido el cine "me consideraba primordialmente marcada por las películas de Godard y Bresson” (“Treinta años”). ¿Qué es lo que ofrece Godard? En 1968 ella escribe en su ensayo "Godard”, la calidad de "mejor director, aparte de Bresson" de su actualidad, aunque asumiendo la distancia que adoptaban "personas inteligentes" irritadas y frustradas por sus películas, "incluso hasta el punto de encontrarlas insoportables" (158). No lo distingue como clásico a la par de Eisenstein, Griffith, Renoir, Vigo y Welles, entre otros, lo asume desde la contradicción: "Los cineastas y espectadores siguen aprendiendo de las películas de Godard y lidiando de ellas" (159). La contradicción, sin dudas, es coherente con una suerte de pensamiento impuro, a tono con las intersecciones constantes de Sontag. En Godard aprecia obras maestras, lagunas fílmicas y experimentación, altos y bajos que requieren ser vistos de manera íntegra (160). Por consiguiente, declara: "Uno de los aspectos más modernos del arte de Godard consiste en que el valor final de cada una de sus películas procede del lugar que ocupa en una empresa de más enverga- 
dura, en la labor de toda una vida. Cada película es, en cierto sentido, un fragmento que, en razón de la continuidad estilística de la obra de Godard, arroja luz sobre los otros" (160). En la entrevista de Cott, es ella misma quien postula la honorabilidad del fragmento, en tanto al "modo en que apunta a los huecos, los espacios, los silencios que hay entre las cosas" (Cott 69), aunque a la vez, es una forma de decadencia, ya que refiere al "final del estilo de una era" (69). En ese sentido, Godard es un campo cuyo espesor se configura desde esa dualidad del fragmento, en lo referido al hueco y a la decadencia, en sí.

La decadencia del cine asimismo afecta al "gran Godard", reconoce Sontag con pesar, ya que este "se dedica a hacer videos sobre la historia del cine" ("Un siglo"), ocaso que, paradójicamente, ofrece uno de los hitos cinematográficos del cine: Historia(s) de cine. Godard desarrolla un cine filosófico donde los elementos visuales y fotográficos "son solo la materia prima”, por lo que será el lenguaje el "ingrediente transformador" ("Godard” 199), cuya opacidad y coactividad le fascina. "Detrás de la locuacidad importuna” de sus películas, continúa Sontag, "se oculta una obsesión por la duplicidad y la trivialidad del lenguaje” (“Godard” 201). En las líneas dedicadas a Godard convergen la cinefilia y lo que su hijo denomina, en el prólogo de La conciencia uncida a la carne, "ejercicios de admiración" o "actos de homenaje" ("La conciencia"), siempre vinculados a la pasión y al goce como ejercicio crítico.

Los dos ejes señalados, gruesos en su articulación, ponen de manifiesto maneras de problematizar el cine y de canalizar la cinefilia de Sontag, en sí, maneras que apuntan al fundamento de Sontag de escribir para cambiar sus ideas, creando, de paso, un dispositivo de reflexión crítica y teórica, de desmarque continuo, atento a las constantes y a las dispersiones.

\section{Conclusión}

En general, ¿qué es lo que busca Sontag en y con el cine? El cine, según desarrolla Schreiber en su biografía, "debía adquirir una función estética de modelo para otras artes" (158), desde donde construye y aplica un "instrumental filosófico riguroso" a producciones dispares como las de Godard o las de ciencia ficción norteamericana de los años cincuenta, "introduciendo así un aire semiacadémico en la crítica de cine" (159). Sontag cree, agrega Schreiber, que las películas, "mediante la percepción que provocaban de la realidad, podrían tener una función educadora poco común”, no solo en el sentido de una formación estética, sino también en el sentido de una ampliación de la sensibilidad, por así decir, una educación sentimental" (160).

El ejercicio de escritura, sin duda ensayístico, que desarrolla Sontag, articulado desde la intención de cambiarse, de desembocar en un pensamiento dinámico y cambiante, resulta coherente con el dispositivo teórico y cinematográfico que configura, desde la pasión, la formación y amateurismo, siempre a contrapelo de la academia 
y el poder. Así, se configura una cinefilia al servicio de una función estética y una "educación sentimental" como modelos de análisis cinematográficos que acerquen objetos dispares. En Sontag se trata de una forma de goce y deseo al ver y leer el cine desde la voracidad. Su pensamiento conecta, atraviesa ideas y disciplinas, disfruta del atrevimiento de las obras cinematográficas. En la línea de Rancière, que propone un amateurismo que impugna la autoridad, Sontag experimentó una cinefilia desmarcada de taxonomías rígidas, una cuyo presente, en los años sesenta y sesenta, desapareció en los ochenta y, sobre todo, en el centenario del cine. Acorde con su pensamiento, no queda una estela nostálgica de esa cinefilia, de surgir otra, esta irá de frente con el presente y articulará un pensamiento propio.

Hacia el final del segundo tomo de sus diarios - La conciencia uncida a la carne: Diarios de madurez 1964-1980 - piensa que debe dejar de escribir ensayos, "porque inevitablemente se convierte en una actividad demagógica. Parezco la portadora de certezas que no poseo - ni estoy más cerca de poseer" (La conciencia), asume, entonces, que no está escribiendo para cambiar. La especie de amor que inspira el cine tal vez imposibilita dar cuenta de un pensamiento o dispositivo acabado en Sontag, pero sí uno en continuo movimiento. El goce, el placer, el amor que convergen en el cine, lo plasma como algo complejo de aprehender. El ejercicio de este artículo es un intento por seguir esas huellas dispersas, atentas al devenir cambiante del pensamiento de Sontag.

\section{Referencias}

Agamben, Giorgio. ¿Qué es un dispositivo? Buenos Aires, Adriana Hidalgo, 2014.

Barthes, Roland. El placer del texto. México, Siglo Xxi, 1993.

Benjamin, Walter. "La obra de arte en la era de la reproductibilidad técnica". Estética de la imagen. Buenos Aires, La Marca Editora, 2015.

Cott, Jonathan. Susan Sontag. La entrevista completa de Rolling Stone. Santiago, Ediciones UDP, 2014.

De Baecque, Antoine. Nuevos cines, nueva crítica. Barcelona, Paidós, 2006.

De los Ríos, Valeria. “El cine según Slavoj Žižek”. laFuga, 7, 2008. [Fecha de consulta: 29 ene. 2019] Disponible en: http://2016.lafuga.cl/el-cine-segun-slavoj-zizek/18

De Valck, Marijke y Malte Hagener (eds). "Down with Cinephilia? Long Live Cinephilia? And Other Videosyncratic Pleasures". Cinephilia Movies, Love and Memory. Ámsterdam, Amsterdam University Press, 2005.

Fecé, Lluís. "Prólogo". Teoría y crítica del cine: avatares de una cinefilia. Antoine De Baecque. Barcelona, Paidós, 2005.

Maniglier, Patrice y Dork Zabunyan. Foucault va al cine. Buenos Aires, Nueva Visión, 2012.

Rancière, Jacques. El destino de las imágenes. Buenos Aires, Prometeo, 2011. 
-_. Las distancias del cine. Buenos Aires, Manantial, 2012.

Schreiber, Daniel. Susan Sontag. Intelectualidad y glamour. Una biografía. Santiago, Tajamar Editores, 2016.

Sedeño Valdellós, Ana. "Nueva cinefilia: reflexiones sobre la transformación de las prácticas cinéfilas por las nuevas tecnologías de la contemporaneidad". Razón y palabra 83 junio-agosto, 2013. [Fecha de consulta: 5 feb. 2019] Disponible en: http://www.revistarazonypalabra.org/index.php/ryp/article/view/526

Sontag, Susan. Against Interpretation and Other Essays. New York, Picador, 1966.

——. "Godard". Estilos radicales. Barcelona, Muchnik, 1985.

-—. "Un siglo de cine”, “Treinta años después..., "La escritura en sí misma: acerca de Roland Barthes", "De la novela al cine: Berlin Alexanderplatz de Fassbinder". Cuestión de énfasis. Barcelona, Penquin Random House, 2011. Ebook.

-_. La conciencia uncida a la carne: Diarios de madurez 1964-1980. Ebook.

- - . "Fascinante fascismo", "El Hitler de Syberberg". Bajo el signo de Saturno. Barcelona, De Bolsillo, 2017.

- - " "La caverna de Platón", "Estados Unidos visto por fotografías, oscuramente". Sobre la fotografía. Buenos Aires, De Bolsillo, 2017.

Vergara, Ximena. "Cinefilia temprana. reflexiones a partir de las columnas de María Wiesse y León Klimovsky”. Revista de Humanidades 37 (2018, enero-junio), 39-62. [Fecha de consulta: 10 ene. 2019] Disponible en: http://revistahumanidades.unab.cl/wp-content/uploads/2018/05/Art.-Dossier.-Cinefilia-temprana.Vergara.pdf 